\section{LAW AND FORCE IN. PAPUAN SOCIETIES}

By R. F. FORTUN

THE aim of this paper is to give a general conception of Papuan social cul ture from a legal aspect, and to draw permissible inferences in regard to inter-municipal law. We may begin by giving a sketch of the laws of a Papuar tribe resident between $145^{\circ} 30^{\prime}$ and $146^{\circ} \mathrm{E}$., and at $6^{\circ} 15^{\prime} \mathrm{S}$, in central New Guinea. These people live on the headwaters of the Kamamentina River and in the absence of a tribal name in their instance we may term them Kamamen tina River people, and their law K.R.P. (Kamamentina River Papuan) law The laws of primitive people are, in the main, of the general type of inter municipal law, of which inter-clan and inter-district law are primitive instances and international law a civilised instance. The K.R.P. did, however, have some little municipal or clan law, as well as somewhat more inter-municipal o inter-clan law. We may mention furst the municipal law.

The norm of law regulating marriage was that no man might marry a woman of his own village. In case a man violated this norm he might expect to have to fight his new father-in-law with strakes of wood, and to have his violation of the norm generally condemned. But he established his breach of the norm. The norm of law regulating the state of a widow was that the male next of kin took the deceased's widow in remarriage. There was sometimes some dispute over which man was most eligible to exercise this right. In case of dispute between fellow villagers and clansmen over the hand and the heart of a widow, or over the right to work a particular plot of land, or over any other common cause of dissension, the disputants usually made a determined effort to settle the case by discussion. If this effort failed, and the conflict continued the contestants reached for strakes of wood and attempted to batter each other's head and shoulders. When an argument reached this stage it was nor mal for the man who drew the first blood on his opponent to claim a victory a law, and it was normal for his opponent to concede the lady, the land, or what ever it might be to his fellow. The process was, of course, strictly legal, sinee there is no reason other than the reason of respect for a legal norm, why the man whose blood was first drawn should concede the case as he did. In case of a man discovering a fellow villager and clansman in adultery a duel migh: follow, usually resulting in wounds. Sometimes a man discovering a fellow villager in flagrante slew him. In this case the homicide and his next of kin paid compensation to the next of kin of the dead adulterer. Those who received thiss. compensation forewent the right of one of them to take the widow in re marriage, and gave her in marriage to the man who had killed her husband.

Although settlement of disputes between clansmen was made independ ently of any norms of inter-clan law, yet related persons of other villages and clans had a right to exercise their interest in blood shed in the course of dispute

Whe clans in this area are constituted of lineages in the male line. These Hineages are conceived to be related by converging common ancestry. AccordIng to the law of marriage the mothers of clansmen came from out of clan, and the maternal relatives of clansmen were accordingly persons of other clans. a.d villages in the neighbourhood. When a man's maternal uncles and maternal 10iroles' sons heard that their kinsman's blood had been shed, they came to visit 11 m with ashes on their heads and with clay daubed over their bodies. They 6iteught their entire clan with them. The uterine nephews and cross-cousins ${ }^{1}$ weete then obliged to kill pigs to feast their maternal relatives and those who aceompanied them, who might number between forty and a hundred men. They were also obliged to pay their maternal relatives in potash salt, bows and anows, and ovalum and cowrie shell ornaments. The maternal uncles and the maternal uncles' sons, in accepting this payment made for bloodshed which dey regarded as substantially their own, exercised a right founded on religion 8nd on a dogma that a man's blood comes to him from his mother. This partic1ar norm of inter-clan law and this dogma have a wide distribution amongst 4. 4 puan tribes. There was no dispute of the right of the maternal relatives to tollect this payment, short of war with their clan. Just as there were no 1unicipal legislatures, courts or militia, so also there were no inter-municipal rigans of law. The costs of payment for blood shed in a municipal dispute were tery substantial in terms of the native economy.

1. The norms of inter-clan law in this area include norms regulating marriage, 201d norms regulating behaviour in war. In norms regulating marriage there is 4. Eustom obligating a husband to give a full-grown domestic pig to his wife's tentives when his wife bears her second child. The wife's relatives give a thecrprocal gift of a shoat to the husband on this occasion. When the children Wecome adolescent and undergo certain rites of initiation their father is 4hilgated to give a joint of pork to his wife's brothers. The donor loses nothing 47y this gift, as his wife's brothers give him a counter-gift of a similar joint of $40, k$ on some later occasion. When a man's wife dies the widower and his Chansmen are obligated to kill pigs to feast all comers from most of the surwinding villages. At the wake that is held at the death the widower is expected to give the brothers of his deceased wife a whole cooked pig, parcels of potash sat, bows and arrows and cowries and ovalum shell.

The norms of inter-clan law regulating behaviour in war include provision (o) the maintenance of marriages between members of warring clans; provision 16. I the maintenance of levirate law, so that war-widows may be returned by Ther brothers to an enemy to remarry a brother or a near relative of a slain rinemy, as they would have been remarried, with the agreement of their 710thers, had their husbands died in peace, or as allies; exemption of men trit Thus, Frazer: "It

In the case of ortho-cousins the related parents are of the same sex, whether the or both female; whereas in the case-cousins the related parents are of opposite exes, the one being male and other female." 1919, p. 98. 
from personal service in war against the clans of which their mothers wer born, and against the clans into which their paternal aunts had married; ant frequent reception and protection of routed refugees by protecting clans in the name of kinship between a few members of a body of refugees and a few men bers of the protecting clans.

In wars between clans there were always some women involved whos husbands had taken up arms on behalf of their clan against their wives brothers. Women related to these men were permitted to walk between thi firing lines, across no-man's-land, without being molested. When these wome took possession of no-man's-land the shooting stopped for the time of theil traverse. In one case of the kind which we observed two women used thei privilege under inter-clan law to evacuate two wounded men into saffe keeping. They led the wounded men laterally across the centre of no-manto land to the edge of the field, and left them there in the care of a protecting clan who were watching the fighting at that stage of the war, and who did not be come active till a few days later, when they fought a rear-guard action to heip to extricate their defeated friends. The protecting clan, on receiving the wounded men from the women, sent the men under escort to their own homes to be received there as guests and as refugees. The women retraversed no man's-land and rejoined the party whose wounded they had just evacuatet from the field. In another case of the same general kind observed, a woman crossed the lines from her brother's party to her husband's party one evening towards dusk, and the shooting ceased on both sides to give her unmolested passage. A rout of her husband's party, outnumbered ten to one and exhausted after several days and nights of fighting, seemed very imminent, and he purpose was probably that of fulfilling her domestic duty of assisting in the carriage of pigs and of shell-money in the rout. We believe that this particulat woman may have been one killed by error in the night. when the rout 0 c curred; for we observed the victors returning from the pursuit early nex morning threatening an ally in the victory with their certain enmity in the nex war. We enquired the nature of the matter in dispute, and we were informe that the ally had shot down in the dark a daughter of one of the familiesoot their principal, married to an enemy. If the woman killed was not the one observed crossing the lines towards dusk, it was one other who had a simikg status, for only those women who have brothers in one principal party and husbands in the other have rights of unmolested passage. The violent deathiof a woman without this status does not arouse equal comment.

This norm of provision for the maintenance of marriages between member of warring clans, violated sometimes by inadvertence, is very evidentis sanctioned by threat of war and reprisals against those who violate it. In th instance observed the ally threatened with war and reprisals departed 10 mediately for its own territory without staying to claim any plunder from $t$
Then of the routed clan. The custom of remarriage of a widow to her husdat d s brother or next of kin is commonly maintained between enemies, and t. 4. 16. a war-widow of their own making across the lines in prospective reriartrage to an enemy of that time. We also observed one instance in violation of the law in which a war-widowed sister was retained and given to an ally, instead of to the enemy to whom she might else have more lawfully reverted Wiex remarriage. These norms of inter-clan law providing for the maintenance temarriages between members of warring clans clearly follow contracts given 1.6 1 e ersons who become enemies, for as Grotius, writing on European interna16 al là ${ }^{2}$ says, "Under the character of enemies men do not lose their right th the fulfilment of a promise." Since it is the law on the Kamamentina Rer for a widow to revert in remarriage to another member of the clan of her ate tusband, the killing of a sister's husband in war is not held to annul a naririage contract between the families and clans concerned.

Th ${ }^{2}$. consideration of the norm of inter-clan law which exempts men from 9ersonal service in wars against the clan of which their mother was born, or gavint the clan into which their paternal aunt has married, we may note that 7. anibassy within one another's territories. However, in the making of alliances 102 commonly played the part of pleaders for alliance with the clans of which 7eir mothers were born, or for alliance with those into which their paternal 2017ts had married. When an individual's plea for alliance with the clan of his Thernal uncles' sons or with the clan of his paternal aunts' sons was rejected, 3rd the council of his own clan decided on war against such a clan, instead of Ia nce with it the cousins (cross-cousins) on each side were exempted from fextsonal service in such a war. They were not exempted from service more a 2 perally, and we observed the same individuals in action in some wars, but 61 6 others, in proof of this fact. The fathers of these cross-cousins, who tere in a wife's-brother and a sister's-husband relationship to each other, were 2. 6 means exempted from personal service against each other, in case of war Theen their clans, as their adult sons were in such case exempted. The icotecting clans who frequently received routed and refugee clans into their Wh territories in the name of kinship between a few members of their clan and fev members of a refugee clan were sometimes allies in the war that was lost. The protecting clan that one day received two wounded men evacuated by ornen, and that finally fought a rear-guard action to help extricate its friends 10 1 incident which we have mentioned above, had, for example, four or five 1ts members who were cross-cousins (maternal uncles' sons or paternal in (s's sons) to members of the fighting clan to which they gave limited aid. In 
that incident these particular four or five members of the protecting clan took combatant service each day by the side of their fighting cross-cousins. Their clansmen declined to commit themselves as a body equally actively, possibly since the odds against them were overwhelming in number. They evacuated their own combatant members every evening from the field, went home to their own territory to sleep, and returned to the side-lines of the field early every morning. When they were threatened they merely withdrew, and then returned to the side-lines when the threat was withdrawn. They performeda service in actively extricating their own members and most of their friends in the sequel, and in giving the routed clan hospitality in their own territory. The allied clans or protecting clans which give aid in war or hospitality and protection in defeat to any particular clan vary from year to year. In a history we noted that Avavi village aided and protected Fukaminofi village routed by Faganofi. A year later Avavi were in alliance with Faganofi against Fukaminofi who were routed again, and protected this time by Ndjaraguna village. When Avavi took enemy action against Fukaminofi, the cross-cousins who had negotiated the alliance of the previous year between those villages were exempted from service on either side, according to the norm of law which governs such cases. In the events of the time of the Avavi-Faganofi alliance, which we witnessed, Faganof opened the war by shooting-down two young men of Fukaminofi from ambush. These two young men had, it was said; brides from Avavi. The Avavi people were not unduly concerned about this They said laconically; "It is of no consequence; we have given our daughters to them in marriage forever in any event." They joined Faganofi, and also offered pay to Kumuina village to join them both as an ally.

We have said enough here to describe fairly the laws of this Papuan tribe They had not much law. It is clear enough that although they had a little municipal law, most of their law was of the inter-municipal type. It has been suggested by Grotius, the first writer to formulate European international law, that there is a kinship amongst men established by nature; that in this bond there is a community of rights and of duties; that the terms of kinship amongst men established by nature bring about a natural law which is an expression and a dictate of good reason; and that the dictates of good reason and of morality which cannot be set aside without abrogation of reason and of ethics will endure throughout peace and war alike.

This suggestion may be well received as a theory of the character of inter municipal law. In view of the character of inter-municipal politics, however, it may be noted that there is no certainty of securing legal definition of the rights of clans, districts or states, interpreted by disinterested parties. The community of rights and duties which is legally defined in the K.R.P. instance, and in many other primitive instances, is somewhat restricted to terms of kinship amongst men, modified by convention. Systems of positive inter-municipal
Itw are commonly maintained by good will or consent, and are not necessarily abrogated by the occurrence of war and reprisals. It may not be correct to suppose that war and reprisals or the threat of war and reprisals is generally ased as a sanction for violation of the norms of positive inter-municipal law; Tor some of the norms of inter-municipal law presuppose war and reprisals. Moreover, according to the principle which international lawyers call the rule of unanimity, and others the privilege of veto, a method of coercion cannot be tegally employed by one power against another without the other's consent. It follows, if this principle is accepted; that the area covered by the law is an area of consent, and that the law does not include social custom which falls outside the scope of the rule of unanimity. In our sketch of K.R.P. law we noted an instance of a clan threatening an ally with reprisals, because the ally had violated a norm in protection of a daughter married to an enemy. However, in that case the violation was inadvertent, due to the darkness and confusion of a rout at night; and there is no suggestion that the norm in point is not based on consent; or that it usually requires threats of a sanction for its observance. Still Iess is there any suggestion that K.R.P. war and reprisals in general occurred as a sanction of norms of law.

In order to clarify the theory of the relationship of law to force at this point we may notice that the K.R.P. considered a peaceful death of a man to be an occasion for feuding, since they conceived a peaceful death to be due to magical soul-stealing done for pay. They set out to infilict punishment upon Sovi-stealing magicians, their clansmen, and the clients who paid them. In reprisal, soul-stealing magicians were frequently employed on all sides, but 2irthaps a little more especially by the defeated against their victims than conversely. The implication of these facts, as far as the law is concerned, is 7.at K.R.P. law did not extend into the field of theology, or into the field of coonomics at the point where payments were made for soul-stealing or for the tetformance of ambush killings or for alliances in war. These fields were fields 6y convergence in custom. Rates of pay for soul-stealing magic or for killings 6.t alliance were, for example, uniform. But convergence in custom out of law 45 commonly and correctly distinguished from consent according to the 12irciple of unanimity which resides within law. We need not doubt a conXivion that inter-municipal law depends upon good will and consent; whereas reprisals and feuding do not depend upon good will or upon consent, and chore the rule of unanimity.

(1) The K.R.P. instance there was serious fighting between the neighbouring and intermarrying clans of the one linguistic unit or tribe. We may now Thention a different Papuan instance in which there were only six settlements it the one language unit or tribe, and serious fighting occurred outwardly more inan inwardly.

The Mondugumor who live on the Yuat River, a tributary of the Sepik 
River, New Guinea, had a norm of marriage by exchange of women. A Mondugumor woman named Mongia was the mother of two sons, Ulishok and Marakia, and of one daughter, Maioi. It was clear that Ulishok and Marakia could not both of them exchange Maioi for a wife. They disputed the problem of which one of them should marry, and fought with knives over the point. Mongia, the mother, intervened and sternly reproached the younger son, Marakia, for disputing his elder brother's priority. Marakia, bearing no weapons, but carrying the knife with which he had fought with his brother, paddled his canoe downstream to the first village of the next tribe, who were enemies of his people. That night his people heard the sound of the dance of blood from Andua, the enemy village down river. Mongia, the mother, cried for her son all night. Before dawn she paddled her canoe alone down river. When she reached Andua she said to them, "Do not kill me quickly, but show me first the fireplace where you cooked my son, Marakia." They agreed and led her to the fireplace in silence. She bent over it, cried, and on it she broke the shell arm-rings of Marakia which she carried with her. Then she said, "Do not cook me over any different fireplace but over this one." This was done, and reported.

Ndemverop, the younger sister of Malome, visited her sister in her sister's husband's house. Alemi, head of the house, seduced her and then proceeded to install her openly in his household, which already included several wives. Malome in outrage. said to her younger sister, "You should kill yourself for shame." Ndemverop paddled alone down river to Andua where they killed her and ate her. This incident occurred not long after the suicides of Marakia and of his mother, Mongia. A raiding Andua war-party had also surprised and killed some men of Vroang hamlet. So all the men of the six Mondugumor settlements with some allies from the potters who live between the Yuat and the Keram rivers, and from the mosquito-proof sleeping-bag makers who live between the Yuat and the South-East rivers, went down upon Andua by night. They surprised one hamlet of Andua settlement at dawn, killed all the men, women and children in it, fired the houses and smashed the wooden slitgong drums. The butcher of Ndemverop, however, escaped as he hid himsel on a roof and was overlooked in the smoke from neighbouring houses on fire

Since our aim is to give a general conception of Papuan social culture from a legal aspect, and since we need more fact as a basis for such a conception, we may now discuss the practice of black magic for pay amongst the Arapesh people, resident near Wiwiak, New Guinea, at $143^{\circ} 30^{\prime} \mathrm{E}$., and $3^{\circ} 30^{\prime} \mathrm{S}$. In particular we shall discuss an incident where some natives indicted sorcerers before an Australian magistrate, overcoming their fears of the system of organization of magic and their prudence in thinking to conciliate and to propitiate men who would, after all, get no more than a short term of imprison? ment. We quote from official correspondence on the subject, revised here for the sake of completeness in the record.

\section{Dear Fortune,}

These police are going in to investigate and arrest natives for sorcery activities. The complaint comes from a large number of village officials. The natives accused are (a list of names).

If you happen to know anything which would assist me in the matter I would be greatly obliged if you would let me know.

Dear B-

The magical art is a mystical procedure. In any deed of sorcery enacted in this district there are involved an intended victim, a procurer of soul-stealing magic upon the intended victim, and a specialist magician or sorcerer who performs soul-stealing magic for pay at the procurer's commission. The intended victim's soul is considered to be semi-detached from his body. The procurer has come into possession of scraps of food, or clothing, or ornament, discarded or lost by the intended victim, and believed to contain an external part of his soul. The specialist magician seeks to abstract the intended victim's soul by magic enacted over the personal leavings.

In order to do this he places a nettle leaf and a leaf of a heavy timber tree together with the personal leavings in a packet which he puts to smoke over a fire. There is a family line of hunters associated with each family line of sorcerers. The hunters are expected to fish for lobsters and hunt for game to smoke over the same fire as that used for the personal leavings. The sorcerer must abstain from family contacts while working at magic, and have his food cooked and brought to him by a woman past the menopause. At the conclusion of the magic the sorcerer places an open bamboo tube on the ground, and when an insect of any kind enters it, he shuts it into the tube. The insect inside the corked bamboo tube represents the intended victim's soul.

In this district sorcerers all live in villages on the most inland strip of the tribal country. They have privileged entrance into the internal affairs of some other villages than their own all the ten-mile-way from the Torricelli mountain watershed to the seacoast. There is, as far as I know, no curing magic. Sorcerers are neither personally friendly nor personally unfriendly. They merely work for clients who pay them. The payment accompanying a commission to perform soul-stealing magic is called butum. When a sorcerer receives payment, and personal leavings, and a commission to perform soul-stealing magic on the personal leavings, he may send a messenger carrying a bird's feather to the intended victim. The person receiving the bird's feather has then an op 4 tion on making a payment to cause a stay from action by the magician. The payment 5ometimes made to induce the practitioner to desist from fulfilling his commission is Falled waluwahiku. When a man falls ill his kinsmen often seek out a man of their acouaintance in the sorcerer's country and ask his ajd. The man whose aid is asked then tengages in a search for the identity of the sorcerer who has received butum payment Tor the case in point, in order to be able to offer that person waluwahiku payment to desist from his soul-stealing. Such a search is not undertaken for pay, but by one person to. oblige his acquaintances.

The forwarding of the personal leavings and of the butum payment to hire sorcery 
was done by relay, and by persons of confidence in one another from one local group to another, until the commission reached the sorcerer at the inland end of the relay line: The duty of the kinsmen of the ill man or of the dead man was to go travelling from place to place on far-off trails to discover the origins of the butum payment in or near their own home locality, and the terminus of it in the sorcerer's country over the moun? tains, in order to offer waluwahik $u$ payment to the sorcerer to desist or, if their kinsman died, in order to put the right suspects in their own locality through ordeal to determine died, in order to put the right suspects in their own to see a group of Arapesh men seeking to establish the identity of their evil-wishers in the magical line gathered in a halfcircle round a suspect staring at him very hard indeed while he eats some of his accusers food. If the suspect cannot contain the food under the staring ordeal, but vomits it or fails to swallow it, he is judged to be the wanted man. His accusers do not usually assault him bodily as a result of such judgment, but they believe they have his external soul in the remnants of some food he has tried to eat, and they hire a sorcerer to work on these and take his soul from his body by magic.

The men indicted by your plaintiff, as I see from your list, are all men of the inland fall. The plaintiffs are all men of the coastal fall. You have possibly a case of the $\mathrm{n}$. tended victims of evil magic indicting the alleged magicians that some procurers have paid to perform the magic.

\section{Dear Fortune,}

Thank you very much for your interesting and also very useful reply to my request for information regarding sorcery in the Arapesh area. Actually only a certain amoun of information concerning the system you described came out in evidence.

As you are aware, the section regarding sorcery in the Native Administration Reg lations is framed as follows:

Any native who

(a) practices or attempts to practice sorcery, or

(b) threatens any native with sorcery whether practiced by himself or any oth native, or

(c) procures or attempts to procure any other native to practice or threaten an other native with sorcery, or

(d) is found in possession of implements or charms used in sorcery, or

(e) accepts payments or gifts the intention of which is to propitiate a sorcerer $6 \mathrm{r}$

(f) administers or is in possession of a drug assuredly used for unlawful purpost

(f) administers or is in possessio
shall be guilty of an offence.

Penaity. Three pounds or imprisonment for six months or both.
I charged Limbabo of Dunigi with receiving gifts under (e) above. He appeared $x+0$ be the chief man concerned. Gifts received from Umbum of Alitoa included one plate one knife, one mug. The result was a sentence of four months' imprisonment and $\mathrm{fl}_{\mathrm{fi}}$ returned to Umbum. Nugut of Bonahitum similarly charged and sentenced. Kabimani and Sabiwen, both of Dunigi, were charged with threatening sorcery. They threatene and Sabiwen, both of Dunigi, were charged with threatening sorcery. They threatenteres
the natives of Suapali because at a feast Suapali did not give them food. Sentence Kabimanui two months, as leader, Sabiwen one month, as follower.
Dear B

I met Limabo of Dunigi village four years ago when I visited him with his Alitoa friends, one of whom, Umbum of Alitoa, has now delivered him up to the law as a recipient of Umbum's pay to propitiate a sorcerer. On the occasion of my visit four years 'ago, Kule of Alitoa was ill, and Kule's relatives, including Umbum, embraced Limabo, smoothed his back with their hands and begged him to find the sorcerer to accept a propitiatory gift. He said he was not the magician who had Kule's case in hand, but he knew who was, and he proceeded to Ehikilum village bearing the propitiatory pay, and returned, without the pay, but with the news that Kule would recover.

I do not know Nugut of Bonahitum.

Wabimanui and Sabiwen I have met frequently, and recently at Suapali village also, where they were charged with threatening sorcery at a feast because Suapali did not give them food. As a matter of fact l saw them given food, eating happily enough. Someone objected to eating from the same platter with them, called them sorcerers, and provoked an incident. Wabimanui certainly did threaten that, if Nyauia village men present did not pay for his nephews, someone in Nyauia would fall from a tree top. It appears two of his nephews have gone to live in Nyauia, leaving their home village, and that Wabimanui considers he is owed something for them.

I agree with you the natives really want to clean up the magical trade. The prositiators and persons threatened are evidently more ready to charge the specialist sorcerers than vice versa, or than the procurers, because they can do so without indicting themselves.

In comment upon the matter of this correspondence we may note that the thagistrate concerned gave the natives a lecture upon the value of seeking medical treatment in cases of illness, instead of seeking to propitiate sorcerers. The court case in point aroused a great deal of interest in the Wiwiak area. In His part of the New Guinea country when a married woman left her busband and eloped to a new man of another native district, inter-municipal affrays lad usually followed in which about four persons were killed and several Wounded. ${ }^{3}$ Also when a young man fell from a tree-top and died of his fall, frays had followed in which about five men were killed and four wounded. the clearing ground for gardening men customarily climbed up the trees and ioped off the leaves, rather than fell the trees. It was dangerous work out on 17e ends of limbs, but death from a false move in such case was believed to fave been caused by sorcery. The affrays that had once followed such a death 16ad been between the kinsmen of the man that fell and persons believed to hix procured the sorcery which was thought to be responsible for the death. suspicion of contrivance of black magic was a cause of some affrays, and a use fiblack magic was considered to be a weapon of terror and of offense auxiliary 60 2 lighting. So the night before a planned meeting on a fighting field, as the girue to a prior ambush killing, each party tried to terrorize the other by 
drumming on the slit-gongs the number of enemy souls they had information were currently in sorcerers' hands. This was the number of the enemy they hoped to kill on the fighting field next day. Again before undertaking a surprise expedition against an enemy, a war party sometimes ascertained from sorcerers which particular man of the enemy had personal leavings already in the sorcerers' country. They then paid for magic for death in war to be done on those personal leavings, and they directed their ambush against the hamlet where that particular man lived.

Although peaceful deaths usually led to reprisals of some nature, there was one exception to this procedure. When an Arapesh man dies a peaceful death, his fellows consider it proper to adorn the corpse, to bury it, to determine the identity of those who procured the evil magic antecedent to the death, and to secure reprisals against the procurers, unless, indeed, it was a woman who procured it. So when an Arapesh man lies dying, his confessors and crosscousins use a set speech of the oral tradition, asking him:-

Does a woman fasten your soul, or a man? If a woman has bound you, tell us of her lest we take an unnecessary duty of reprisals upon ourselves and travel many districts to no purpose. If a far-dwelling woman or a neighbouring woman fastens your soul, now tell us word of her.

If the dying man, under this pressure, confessed an adultery, his kinsmen assumed, without further delay, that the woman in the case had procured sorcery upon the man's soul, thought to be present in this case in his seed. In such case they denounced the need of giving him a proper funeral, and they did not, as far as we know, undertake reprisals of any kind against the woman or against any other person.

In general consideration of the facts of the field which we have mentioned we may notice that when a civilised state sets up an administration in primi tive country it disregards the rule of unanimity according to which one power. cannot legally use coercion against another without the other's consent, and it suppresses customs of reprisals and of feuding in general. The primitives who are subject to civilised administration are obliged to recognize that their own inter-municipal law, based upon good will and consent, within the rule of unanimity between themselves, is not generally in suppression, whereas thei: own inter-municipal politics supported by power motives are repressed. There are some anthropologists who consider that this procedure is equivocal. For example, Miss C. H. Wedgwood, writing on the subject of Melanesian warfare says:

It is generally assumed by the white man that among the backward peoples warfare is an unmixed evil. Because it involves the loss of human life and often a considerafore degree of human suffering, together with much economic waste from the destructiox of villages and the burning of crops, it is held to be right to suppress it rigidly wherever it rears its head, not only for the sake of their white rulers, but also for the sake of the backward peoples themselves and their culture. The same condemnation is not so com monly extended to the military activities of more "civilized" nations, since these ar considered to be different in kind and in aim from those of primitive folk. From the sociological point of view it is probably safe to say that both these assumptions are largely false. The more we study the cultures of people both "savage" and "civilized," the more it becomes apparent that no social institution comes into being and continues to flourish unless it has a definite function to fulfil in the culture of which it forms a part. This is as true of war as of any other institution, and, though the immediate causes of war are diverse and there are different forms which it may take, yet, as I hope to show from the following analysis of warfare in Melanesia, one of its constant functions is to strengthen the bonds of union between the individuals of the fighting community and make them jocreasingly conscious that they are members of a single unit. ${ }^{4}$

Personally we do not consider that the general procedure of civilised administration of primitive country is in fact equivocal. A "culture" is merely a state of the arts and sciences, including the arts of law and of political organization. It is doubtful whether reprisals and feuding have any use in the advancement of the arts and sciences in general, or even in the art of political organization in particular. Moreover those writers who condemn the military activities of primitives often do include the military actions of civilised peoples in a general condemnation. Thus Sir James Frazer:

For the state of war, which normally exists between many, if not most, neighbouring tribes, springs in large measure directly from their belief in immortality; since one of the commonest motives for hostility is a desire to appease the angry ghosts of friends, Who are supposed to have perished by the baleful arts of sorcerers in another tribe, and tho, if vengeance is not inflicted on their real or imaginary murderers will wreak their fury on their undutiful fellow tribesmen. Thus the belief in immortality has not merely coloured the outlook of the individual upon the world; it has deeply affected the social and political relations of humanity in all ages; for the religious wars and persecutions, Wich distracted and devastated Europe for centuries were only the civilised equivaints of the battles and murders which the fear of ghosts has instigated amongst almost 1) races of savages of whom we possess a record.

It is true, on our own endorsement, that inter-municipal law is not indusive of the field of primitive theology. However, tribes who desire to gropitiate or appease the ghosts of friends commonly develop extensive systems of religious practice, along these lines, typically with mediums, seances, con4 lols and other devices of spiritualist religion. One instance is that of the Wnus tribe of the Admiralty Islands. ${ }^{6}$ The Manus have a little sorcery prac16et also, but they do not take it as seriously as they take the propitiation of thosts; they do not consider appeasing ghosts by taking revenge upon sorcerers Wedgwood, 1930

Frazer, 1913, p. 468.

(rifortune, 1935 . 
for they do not consider that peaceful death is caused by sorcerers in the first place, but they believe it to be caused by ghosts. In their case inter-municipal law was apparently not inclusive of the field of economics, so that they fought some wars over ownership of fishing rights, sago swamps and the like. In general neither Australian aboriginals nor Papuans are equally deeply involved in the propitiation of ghosts with a people such as the Micronesian Manus. Some of them are, on the other hand, very deeply involved in the killing of sorcerers and of their clients, or else in the propitiation of sorcerers and in reprisals upon the clients of sorcerers. It does not follow that these peoples reprisals upon the clients of sorcerers. It does not follow that the not equally heavily involved in that direction.

In the K.R.P. case the village mates of the peacefully dead man do com? monly ask the corpse the question, "Who killed you?" in a ritual of divination common also amongst the aborigines of Australia. They presume that peaceful death is due to malicious soul-stealing. They may be justly considered to be addressing this question to the earth-bound shade of the dead whom they believe to be present, and capable of answering them by a sign. Moreover K.R.P. women are said to prefer not to leave their houses at night, as they are not keen on encountering the earth-bound shades of the dead believed to haunt the place after dark. What remains to be proved to establish Sir James Frazer's contention in this single instance we have in mention is that $K \cdot R \cdot P$. men fear the vengeance of the earth-bound shade if they fail to take aggressive action.

As a matter of fact we encountered only one case of a village of Papuans staying awake and armed all night on account of ghosts. That was not on the Kamamentina River, but on the Sepik River, above Ambunti. In that case a member of the native constabulary had been killed in the village some years earlier. Administration had made the village collectively responsible for the earlier. Administration had made the village collectively responsible for the killing. But no one in the village was known or was ever discovered to have intended, or to have committed, the murder of the constable. Thereafter it int village stay awake and armed all nigh was determined that the men of the village stay awake and armed all niget stayed awake and armed themselves against ghosts. We find it difficult to stayed awake and armed in social psychology, but we are not inclined to 6 列 lieve that the K.R.P. men feared what they though gemies had already as much as they disliked what they thought their enemies had already done At the same time that they sought to divine the identity of their enemies by sign from the earth-bound shade, they also sent out spies to try to discover amongst neighbouring clans the evidence of a possible payment of a pig by clients of one clan to the sorcerers and to the men's council of another dorat When sorcery had, in fact, been done, this payment fell due to the sorcereirs and to the men's council of their clan when accredited results of magical soulstealing had been achieved, and not before.

It may be of interest to record that, in one instance noted, the sorcerers and all their clan fled after one of their men was ambushed and killed. As they ran they admitted that the spies of their enemy had detected them in receipt of payment for sorcery done against their enemy, and they claimed that they, by their magic, had already taken a life for a life. The imputed clients of these sorcerers were of a different village. They were said to have been detected in paying for the sorcery they had previously ordered done, and two of their young men were ambushed and killed, and a third severely wounded. They stood their ground and fought, against heavy odds, in an affair that culminated to their disadvantage. We discussed their enemies' claim that they bad prevousty ordered sorcery done with them during the action. However, we found that they were not in a mood to admit or even to deny the claim. So we took their children out of the lines at night, gave them housing in our camp, with the consent of their parents, and let the matter go at that.

In the Arapesh case the fear of the earth-bound shades of the dead is associated with an anxiety that the wild boar may break the garden fences, and root up the crops. In this connection we may note that many Papuan and Tapuo-Melanesian tribes rely on the wild boar to mate with the domestic sow. They keep only sows and barrow hogs in the hamlets. The sows range in the bush by day and return to the hamlets for an evening meal and for sleep. Sometimes the wild boar escorts his domestic mate to the borders of the hamIets and is speared for his pains. Sometimes he is more wary, but finds the gardens, breaks fences and destroys crops. The Arapesh believe that the ghosts of the dead sometimes possess the wild boar and cause him to break garden tences and eat root crops. They advise special courtesy and kindliness to Xidows, because otherwise the ghosts of the dead will take the part of widows, Possess the wild boar and wreck the gardens.

Tne of the Arapesh traditional speeches runs:-

You charm the food you give the pigs. Give a widow a slab of your sago lest she comTains and talks to herself and cries. Ghosts follow near a widow. They possess the wild oar. lead it to the gardens, and it eats root-crops raw. Friends who are now done with Tis property for themeslves possess the wild boar and direct it. A small, small spirit 1- tains in a hollow widow. Take care lest one does nothing but talk to herself and cry. 1. coming days when you butcher game, give a widow the first cut. A widow is your Tior and saw this property before you did. Her husband gave her a bequest. Recently - Weader in this place, died. He gave her a tap on the forehead as she first climbed his toules-ladder [a rite of marriage ceremony]. Take care lest one talks to herself and cries. 4 T.each of custom here and you will strike at the gardens. You will despoil the yam oitsec In future do not discuss a widow as if she were a person apart. Do not think that, cecuse you will inherit the property, you may strike at the dowager widow. Hot upon 
the event of our having buried the corpse I tell you by whatever roads you travel, wher ever you do your work, whatever hamlets you visit, do not stay discussing a widow, as if she were a person apart.

Somewhat more generally the Arapesh consider that any quarrel between relatives is likely to annoy the ghosts of the dead and lead to the wild boar breaking the garden fences. There is no certain indication, however, that when they engaged in feuding and in reprisals they did so in order to appease the ghosts of the dead. There is no indication that feuding and reprisals were considered necessary to keeping the wild boar from breaking the garden fences. It is true that an Arapesh man might, after killing a suspect, call out to the ghost of his son or his brother that he had been avenged for the soul-stealing that led to his death. Nevertheless we believe that Mr. R. R. Marrett is cor rect in saying of an analogous Australian aboriginal field:

Certain authorities discover the root of the matter in the fear of the ghost; but such an explanation reveals a rather shallow psychology on their part, since they fail to assign any reason for the fact that the ghost requires to be propitiated in this special way. True, the ritual proceedings at the grave, whereby it is sought to divine the direction from which the insidious attack was made, usually assign to the dead man the part of accuser-in-chief, as if a sort of clairvoyance were the prerogative of a liberated spirit Nevertheless, all such seeking for a sign is but a crude attempt to rationalise the impulse of men stricken in the dark to relieve their feelings by striking back through the same darkness. ${ }^{7}$

It is a fine point whether some Papuan tribesmen went feuding to appease the angry ghosts of the dead whose souls, they believed, had been stolen from their bodies by sorcerers, or whether they went feuding, as a duty, without special fear of the ghosts of their dead. Personally we consider that the latter alternative is the true one. In either case, however, the field of reprisals and feuding was often connected with their theological views. Personally it seems to us reasonable to point out, in connection with Miss Wedgwood's thesis that military activities are equally breaches of the rule of unanimity in inter municipal law in primitive and in civilised cases. Since inter-municipal law 5 usually restricted by the rule of unanimity, it depends upon consent and upos good will for its observance. It has no real sanctions. Austin, one of the greatest British law writers of the nineteenth century, considered that interer national law was "not law at all, but a branch of positive morality." We mat consider K.R.P. inter-clan law in a similar light if we wish to do so. Personaly however, we prefer to consider inter-municipal law as law indeed, on accoupl of the specific nature of its norms. The fact that such law is also a branch 6 morality does not detract from its legal character. In inter-racial law, a chw lised power does not observe the rule of unanimity between itself and primitive

\footnotetext{
7 Marrett, 1933, p. 53.
}

powers. The civilised power represses the out-law area in primitive intermunicipal politics and theology. The out-law area in international politics continues because international law is restricted by observance of the rule of inanimity between the nations. The only way in which we may reasonably expect control in this out-law area is by the creation of an international militia, not restricted by the rule of unanimity between the nations, acting on behalf of the interests of the majority, regardless of their national affiliation, and extending the field of unanimity in law.

Frontier Areas Admintstration RANGOON, BURMA

\section{BIBLIOGRAPHY}

TORTUNE, R. F.

1935 Manus Religion. Proceedings of the American Philosophical Society. Philadelphia.

1939 Arapesh Warfare. American Anthropologist, Vol. 41, No. 1.

TRAZER, JAMES $G$

1913 The Belief in Immortality, Vol. 1. Macmillan, London.

- 1919 Folk-lore in the Old Testament, Vol. 2. Macmillan, London. Grotius, HUGO

1901 The Rights of War and Peace. W. Dunne, Washington and London.
4. TrRert, R. R.

1933 Sacraments of Simple Folk. Clarenden Press, Oxford.

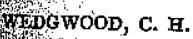

1930 Warfare in Melanesia. Oceania, Vol. 1, No. 1. 